JOURNAL OF SECURITY AND SUSTAINABILITY ISSUES

ISSN 2029-7017/ISSN 2029-7025 (online)

2020 Volume 9 January

http://doi.org/10.9770/jssi.2020.9.J(9)

\title{
Scopus
}

\section{INTERRELATIONSHIP BETWEEN INNOVATION, CORPORATE GOVERNANCE AND ORGANIZATIONS' PERFORMANCE: A CASE STUDY}

\author{
Witthaya Mekhum \\ Suan Sunandha Rajabhat University, Bangkok, Thailand \\ E-mail: witthaya.me@ssru.ac.th
}

Received 17 February 2019; accepted 10 November 2019; published 30 January 2020

\begin{abstract}
The aim of the current study is to investigate the mediating effect of innovation on the relationship of corporate governance (CG) and firm performance (FP) of the pharmaceutical industry of Indonesia. To achieve this objective, a selfadministered questionnaire was distributed among the 400 senior managers of the pharmaceutical industries of Indonesia which yield $77.5 \%$ response rate. The structural equation modeling (SEM) technique has shown that board size (BS), board independence (BI), board diversity (BOD) has significant association with the FP, while number of board committee (NOBC) has insignificant association with the FP. On the other hand, the indirect effect of study also shown that INNO has partial mediating effect on the relationship of BS, BI, NONC and FP, whereas, it did not significantly mediate on the relationship of BOD and FP. This shows that this is not a significant variable on the relationship of BOD and FP of the pharmaceutical industry of Indonesia. The current study added a body of knowledge in the form of empirical findings which could become an area of research in the future. The findings of the current study could provide help to the policy makers and corporate governors to manage the innovation of the organizations to increase their FP. The research limitations and future directions are also discussed in the end of the discussion.
\end{abstract}

Keywords: corporate governance; innovation, firm performance; pharmaceutical industry; Indonesia

Reference to this paper should be made as follows: Mekhum, W. 2020. Interrelationship between innovation, corporate governance and organizations' performance: a case study, Journal of Security and Sustainability Issues, 9(January), 108-121. http://doi.org/10.9770/jssi.2020.9.J(9)

JEL Classifications: I12

\section{Introduction}

In the current environment, the firm performance (FP) are considered to be very important element for the firms in determining their objects and also for achieving success in the modest market place (Rehman, Mohamed, \& Ayoup, 2018; Jermsittiparsert \& Boonratanakittiphumi, 2019; Sriviboon \& Jermsittiparsert, 2019; Arniati, Puspita, Amin, Pirzada, 2019). In addition, it is a significant indicator for stakeholders, economic growth, shareholders, and for investors of the organizations (Khan et al., 2019). The FP magnitudes are based on two determines, i.e. non-financial performance as well as financial performance of the organizations (Rehman et al., 2018). These depends on structural nature objects that are used to enhance the FP. Accordingly, there are many studies that utilized in equally financial as well as non-financial indicators for the measurement of performance (Kaplan \& David, 1996; Kaplan \& Norton, 2007; Hasanudin, Yuliansyah, Said, Susilowati, Muafi, 2019).

In other words, some researchers also used individually financial performance indicators for determine the performance of an organization (Kariyawasam, 2014) which are based on objective in nature but the performance indicators which are subjective in nature are ignored. On the other hand, modern study authors are suggested that 
JOURNAL OF SECURITY AND SUSTAINABILITY ISSUES

ISSN 2029-7017/ISSN 2029-7025 (online)

2020 Volume 9 January

http://doi.org/10.9770/jssi.2020.9.J(9)

perceptual performance measures are considered to be an essential for a firm only when they want to increase their performance on the long-term bases (Rehman et al., 2018; Hussain et al., 2019).

It is indicated that corporate governance (CG) methods play significant and positive role in improvement of the wealth of firm. CG refers towards a method by which firms controlled and directed. It is stated that CG always takes more attention in observation of the researchers and firms after a hug indignity in WorldCom as well as in Enron field (Ali, 2018). According to the developing economies, perfect governance system serves as an important objective in firms' success that are reduce the possibility of financial crises and conflicts of the management (Ahmad \& Nordin, 2019; Plazzi, Torous, \& Yilmaz, 2019). There are some studies clarified that protect firms and also clarified their shareholders, many controlling agencies are endeavored to eliminate practices which are immoral through applying proper rules and the regulations that remain forbid these natures of the following immoral practices; in the CG practices or regulations that are very important (Rankin, Stanton, McGowan, Ferlauto, \& Tilling, 2012). Furthermore, CG structure recognized the information sharing about duties as well as rights inside numerous contributors in the firms' like external auditor and board of directors and management (Fogarassy et al., 2018; Mansur \& Tangl, 2018). Association of the outside auditors, the firms have efficient CG structure is facilitating an auditor work, if the auditor do their works with diligence as well as honesty.

The firms are face failure because of their poor CG structure and there is very essential to develop the proper CG system in the firms for their improvement (Ahmad, Bin Mohammad, \& Nordin, 2019). In addition, Berkman, Zou, and Geng (2009) further also stated that good CG system plays a positive and significant character to decrease accounting on the behalf of weak CG system. Based on this, the new studies are revealed that weak CG system firms faces a lot of problems in agency and in these types of firms managers gain more personal benefits (Larcker, Richardson, Seary, \& Tuna, 2006). According to the agency theory board of directors are very careful about their individual property as likened along with the other people reserves (Letza, Sun, \& Kirkbride, 2004). Besides, this theory also explain that the significant concern of the CG is provide guarantee to the firms' stockholders that administrative play their character in attaining results that provides them more benefits (Ahmad et al., 2019). In addition, there is one more theory that related towards this concept similarly stewardship theory that is assumes an important connection between the successes of corporation as well as shareholder's satisfaction. Steward looks after and increase shareholders wealth by FP for the reason is that by undertaking this activity efficiency roles of the steward's improved (Arora \& Sharma, 2016). Meaningfully, recommended by stakeholders' theory firms search in the place of given balance between its shareholders (Abrams, 1951). Consequently, all the theories about CG suggested for sufficient constructer of the governance that consists the board selection both of the "executive and non-executive directors". Based on previous twenty years' literature, the researchers have paid more consideration in determining the relation within the CG practices and FP. In developed economies pay more attention and much work has been done in area as compare to those economies which are less developed (Barnhart, Marr, \& Rosenstein, 1994; Ebun, 2019; Kotlar, Cuomo, Gaia, \& Zattoni, 2019; Malkawi, 2019).

In the above revealed studies determine the effect of CG on the performance of a firm, results clarified that association exists among these theories. In the developed economies, results are not same as compared towards the developed economies even although with the similar structure and theory (Arora \& Sharma, 2016). Therefore, the association within the CG as well as performance of a firm is a vital area and this theories not conclusive on the other hand further study is also essential (Khan et al., 2019). Conversely, CG is much significant elements for the underdeveloped economies as compared to the developed economies. In addition, this theory also emphasis on the inspection of the effects of CG system as board independence (BI), board size (BS), board diversity (BOD), number of the board committees (NOBC) and FP within mediation effect of innovation influences tin he context of Indonesia. Figure 1 determine the conceptual framework of the present study. The findings of the current study support to the policymakers in this way they could create betterment in the various governance policies like BID, BS, BOD, and NBCM. Furthermore, policy makers also 
JOURNAL OF SECURITY AND SUSTAINABILITY ISSUES

ISSN 2029-7017/ISSN 2029-7025 (online)

2020 Volume 9 January

http://doi.org/10.9770/jssi.2020.9.J(9)

pay attention on the innovation in determining the FP. This study basically provides for introduction of innovation as a mediating variable and its effect on the FP that mostly overlooked in preceding studies of the CG. Present research is containing of the following segments that are; introduction, literature review as well as hypotheses development, research methodology, empirical result, and conclusion and future directions.

\section{Literature review and hypotheses development}

\subsection{Board size, Innovation and firm performance}

According to Khan et al. (2019) board size (BS) characterize the role of both executive and non-executive directors. In line with this, agency theory indicated that small boards inside the firms have extra managerial controls as compare the board which large in size (Ahmad, 2019; Ahmad et al., 2019). In addition, Jensen (2019) also stated that board which is smaller in size is very helpful for the firms to increase their performance efficiency, and also disclose that BS which have more than 7 associates make many issues just like moral hazard issues, deficiency of commitment, ineffective operations, and more control by CEO. Researchers clarified that smaller board has greatly operative to govern the undertaking of a firms as equated to the larger BS that drops the performance efficiency of firms (Al-Okaily \& Naueihed, 2019).

Many writer determine that large size board reduced the efficiency of FP due to its communication gap between them that's why the result of decisions late (Abeysekera, 2010). For instant, large size of board has increases the cost within the relationships of returns and along with the not available significant monitoring that constructed on the firms value inside the market place (Bhagat \& Bolton, 2019). In spite of this, large BS probably to execute the monitoring role inside the organizations inefficient method because many directors are extra involved in process and management (Mbalwa, Kombo, Chepkoech, \& Shavulimo, 2014). The board of directors are operates form various committees created on expertise of boards (Kiel \& Blennerhasett, 1984). For enhancing innovation BS can plays an important role. Therefore, many boards have been considered to be have a large number of expertise that could be helped to the board to improve their performance efficiency and increase innovation as well as FP. According to above studies different hypotheses are recommended.

$\mathrm{H}_{1}$ : BS has a significant association with the FP of the Pharmaceutical industry of Indonesia.

$\mathrm{H}_{2}$ : BS has a significant association with the INNO of Pharmaceutical industry of Indonesia.

$\mathrm{H}_{3}$ : INNO significantly mediates the association between BS and FP of Pharmaceutical industry of Indonesia.

\subsection{Board independence, Innovation and Firm Performance}

This paper follows the controversy within the agency and stewardship theory within the framework of board of directors and also clarified its effect on firm's performance (FP). Agency theory also communicates around objective conflicts among the agent (CEO) and principal (board) as for the firm's agents and working for the improvement of their individual benefits instead of working for principal improvement. According to Kooijman (2017), for the monitoring propose the performance of CEO there must be independent member in the board. In the addition, for increasing of FP agency theory mention the small number of independent directors in board rather than dependent members. The literature determines that independent directors remain beneficial for firms as well as also cost related by certifying that higher figure of the non-executive directors.

A meta-syntheses on the subject of board independence (BI) and FP disclose that there remain conflicting with consequences within these concepts (Dalton, Daily, Ellstrand, \& Johnson, 1998). Many researches demonstrate that the BI enhance the FP (Mbalwa et al., 2014). In spite of this, there are more studies disclose that BI reduce the performance of the firms (Bhagat \& Bolton, 2008; Klein, Shapiro, \& Young, 2005). However, there are many studies that clarified that BID certainly have not influence on performance of a firms (Villalonga \& Amit, 2006). 
JOURNAL OF SECURITY AND SUSTAINABILITY ISSUES

ISSN 2029-7017/ISSN 2029-7025 (online)

2020 Volume 9 January

http://doi.org/10.9770/jssi.2020.9.J(9)

In innovation the BI shows a positive and significant influences (Balsmeier, Fleming, \& Manso, 2017). Based on previous discussions, it is hypothesized that:

$\mathrm{H}_{4}$ : BI has a significant and positive effect on FP of the Pharmaceutical industry of Indonesia.

$\mathrm{H}_{5}$ : BI has a significant association with the INNO of pharmaceutical industry of Indonesia.

$\mathrm{H}_{6}$ : INNO is significantly mediates between the BI and FP of Pharmaceutical industry of Indonesia.

\subsection{Board diversity, Innovation and Firm Performance}

The "resource dependency theory (RDT) and human capital theory (HCT)" clarified the relation within the board diversity (BOD) and firm's performance (FP) of the organizations. The basic objet of the BOD's is consist of to manage the available resources and also to control firm manager's abilities. All the firms depends on their surroundings it is also mention in RDT (Pfeffer, 1972). Firms keep in protection their resources towards their environments and this could decrease the uncertainty and expand the performance of a firms (Taljaard, Ward, \& Muller, 2015). Furthermore, BOD made by classified that board provides that board has the ability for protection of the resources from surroundings and this reduce the uncertainty and increase the performance of a firms (Hillman, Withers, \& Collins, 2009). In addition, BOD's is more superior in protection of their resources on the behalf of minimum diverse BOD's the reason is that board has more access to the double network relationship and have information regarding FP (Taljaard et al., 2015). In addition, the HCT further stated that capabilities and information of the BOD's influence on the efficiency of the application of resources as well as checking characters (Hillman et al., 2009) and also the Capabilities and information of BOD's is also recognized as a human capital (HC) of the board connections.

Moreover, Fagan, Menèndez, and Ansón (2012) also stated that, management should be develop for the innovative and unique information in the organizations. The "HCT and RDT" theory is based on the expectations that the different number of the of board increases FP. The HCT and RDT also discuss that unique HC suggestions the BDV of the firms to increase their FP. In addition, literature demonstrate that board diversity enhance the performance of a firms (Lin, Pantzalis, \& Park, 2010). In spite of this, there remain many studies that disclose that the BOD reduce performance of a firms (Thrikawala, Locke, \& Reddy, 2016). According to Miller and del Carmen Triana (2009), the BOD has a significant impact on the innovation of the organizations. Based on the previous discussions, it is hypotheses that:

$\mathrm{H}_{7}$ : BOD has a significant association with the FP of the Pharmaceutical industry of Indonesia.

$\mathrm{H}_{8}$ : BOD has significant association with the INNO of the Pharmaceutical industry of Indonesia.

$\mathrm{H}_{9}$ : INNO is significantly mediates on the relationship of BOD and FP of the Pharmaceutical industry of Indonesia.

\section{Number of boards committees, Innovation and Firm Performance}

Number of board committee (NOBC) in generally observed as necessary control instruments that monitors the management performance (Lam \& Lee, 2012). Furthermore, board observing objects should be increased to create a NOBC that is permits the BOD's duties to be discharge carefully (Gkliatis, Tsene, \& Koufopoulos, 2019; Spira \& Bender, 2004). Moreover, board committees perform more efficiently when these board committees consists on independent non-executive directors (Lam \& Lee, 2012; Moses, 2019).consequently the board committees increase the firms performance on the other hand in this relationship the empirical studies are less available (Gkliatis et al., 2019). According to this studies three categories of board committees are audit, remuneration and recommendation (Anand \& Singh, 2019). Therefore, literature indicates that board committees has significant effect on FP but furthermost studies which is conducted in developed countries as well as less in the developing countries (Mohammed, Flayyih, Mohammed, \& Abbood, 2019; Puni, 2015). Board committees are associated with firms performance there various studies that are mention this concept (Carter, D'Souza, Simkins, \& Simpson, 2010). In innovation, NOBC has been performed a significant role (Khan et al., 2019; Zulfiqar \& Hussain, 2019). Following hypotheses are available from above studies.

$\mathrm{H}_{10}$ : NOBC has a significant association with the FP of the Pharmaceutical industry of Indonesia. 
JOURNAL OF SECURITY AND SUSTAINABILITY ISSUES

ISSN 2029-7017/ISSN 2029-7025 (online)

2020 Volume 9 January

http://doi.org/10.9770/jssi.2020.9.J(9)

$\mathrm{H}_{11}$ : NOBC has a significant association with the INNO of pharmaceutical industry of Indonesia.

$\mathrm{H}_{12}$ : INNO is significantly mediates on the relationship of NOBC and FP of the Pharmaceutical industry of Indonesia.

\subsection{Innovation, and Firm performance}

Menguc and Auh (2006) is stated that innovation (INNO) resources the firm's tendency to executing the new ideas that are wander from the mutual firms course. Therefore, INV plays ab a significant role in determining performance of a firm (Zaefarian, Forkmann, Mitręga, \& Henneberg, 2017). According to previous studies INNV have a higher influence on the FP (Turulja \& Bajgoric, 2018). In spite of this, literature is reveals that INV have inconsequential impact on the performance of a firm (Darroch, 2005). In addition, there are unsatisfactory results between the innovation as well as performance of a firm and on this stage another variable is require that mediates association among these constructs. There are innovative literature refers towards a creative, risk taking, result oriented as well as is depicted such as being manufacturing ambitious, stimulating, and challenging work situation (Wallach, 1983). Innovative culture are paly a significant character in examining the performance of a firm (Verhees \& Meulenberg, 2004).There are following hypotheses are suggested from the above studies.

$\mathrm{H}_{13}$ : INNO has a significant association with the FP of the Pharmaceutical industry of Indonesia.

\subsection{Research Framework}

Based on previous literature review and hypothesis development section, the research framework of the study is formulated. In the current framework "board size (BS), board independence (BI), board diversity (BOD) and number of board committee (NOBC)" as an independent variable, while innovation is used as a mediating variable and lastly, firm performance (FP) is formulated as a dependent variable. All of these variables is depicted in the following Figure 1.

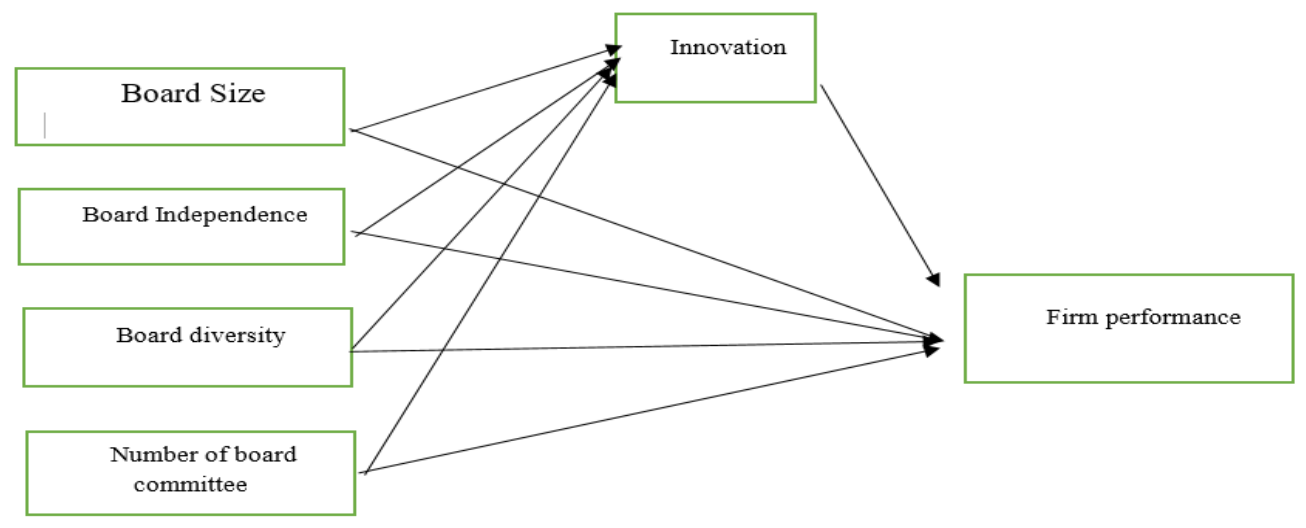

Figure 1. Conceptual Framework of the Study 
JOURNAL OF SECURITY AND SUSTAINABILITY ISSUES

ISSN 2029-7017/ISSN 2029-7025 (online)

2020 Volume 9 January

http://doi.org/10.9770/jssi.2020.9.J(9)

\section{Methodology}

The results of quantitative approach method are based on the questionnaires, it is limited to numbers, statistics, the measurement of data and many forms of statistical analysis. Quantitative research design has been framed for this study, providing assistance to the researcher to thoroughly examine a large sample of respondents; opinions regarding the proposed phenomenon. Moreover, the researcher can take a summarized perspective. In this regard, the researcher used questionnaire the main tool in this research in order to understand the determinant factors that affect the performance of pharmaceutical industry of Indonesia. The questionnaire was designed according to the objectives, problem and hypotheses of the study to determine the relative importance of factors that may control the employees' performance in the pharmaceutical industry of Indonesia. The data collected through the surveys by distributing among the 400 senior managers of the pharmaceutical industry of Indonesia by using simple random sampling technique. The total 310 questionnaires were returned back from senior managers which yield $77.5 \%$ response rate. All of the questionnaires were loaded into the Microsoft Excel, the IBM SPSS, and Smart-PLS. The five-point Likert scale is used to operationalize the variables and their sub constructs. The questionnaire for the independent variables in the current study was adopted from the study of (Honghui et al., 2017). In addition, for the mediating variable that is innovation has been adopted from the (Darroch \& Jardine, 2002). Lastly, in the dependent variable for the firm performance questionnaire has been adopted from the study of (Henri, 2006).

\subsection{Research Analysis and Discussion}

The SEM-PLS, which in modern times is one of the robust techniques to analyses the data on social issues is used as the statistical tool in currents study. Recently many researchers such as Patidar and Din (2018) and Ahmed, Zin, and Majid (2016) has employed and argued that whenever we are dealing with some novelty in conceptual models or need an advance assessment of any existing phenomena, we prefer SEM-PLS over other technique such as multiple regression analysis. Patidar and Din (2018) and Ahmad et al. (2019) and Henseler, Ringle, and Sinkovics (2009) further argued that the PLS-SEM is a two-step equation, which is an advance form of multiple regression and accounts for two assessments namely the inner model assessment and the outer model assessment. The first step is estimation of the reliability and validity of the model. In Smart- PLS, after obtaining the results of reliability and validity for each construct, examining the structural model results is necessary in order to test the hypothesis. There are five steps of procedures in examining the structural model results; (1) examine the structural model for collinearity issues; (2) the significance of path coefficients; (3) followed by examining the level of $\mathrm{R}^{2}$ values; (4) assessment of $\mathrm{f}^{2}$ effect size; and last but not least, (5) examining the predictive relevance $\left(\mathrm{Q}^{2}\right)$ (Hair, Hollingsworth, Randolph, \& Chong, 2017; Henseler et al., 2009). The reason why the SEM-PLS is preferred our the multiple regression is that the earlier handles the multiple equations simultaneously and can produces results with a simultaneous operation by producing a relationship with all direct and intervening phenomena. Reliability analysis is performed in order to find internal consistency of the items. Cronbach's alpha is the most widely used in order to test the reliability level. Although there are many findings that founds that the value of composite reliability is always higher than Cronbach's alpha. An indicator declared as valid and significant if it has a loading factor over than 0.5 on the targeted construct (Hair et al., 2017). Thus, this study analyzed the output of the loading factors which gained thru Smart-PLS. Before testing the hypothesis, data reliability and validity was scrutinized. These steps were taken through PLS 3. It is revealed in Table 1 depicted that all the factor loadings are greater than 0.5 , and also the average variance extracted (AVE) is also greater than 0.5 and in addition composite reliability (CR) is also higher than 0.7 (Hair et al., 2017). Therefore, it is concluded that present study fulfills the criteria of the convergent validity. A measure's content validity refers to the level to which the items produced for it measurement appropriately measures the concept intended to be measured. More importantly, the entire items developed for a measurement of a construct have to load greater on their construct compared to other constructs and this is 
JOURNAL OF SECURITY AND SUSTAINABILITY ISSUES

ISSN 2029-7017/ISSN 2029-7025 (online)

2020 Volume 9 January

http://doi.org/10.9770/jssi.2020.9.J(9)

guaranteed through an extensive literature review. Through such a review, the items that have already been established in literature in terms of their validity are selected. On the basis of the results of the factor analysis, it was confirmed that in this study, the developed items correctly loaded to their respective constructs. According to Hair et al. (2017) convergent validity can be examined through factor loadings, reliability analysis, and composite reliability. Furthermore, Average Variance Extracted (AVE) also examined as one of measure that is useful in establishing validity (Hair et al., 2017). Since by analyzing the convergent validity, it can ensure that the variables correlate well with each other within their parent factor, either mediating or dependent variable. For the discriminant validity, HTMT, cross loadings and Forner Lacker have been discussed in the previous literature (Henseler, Ringle, \& Sarstedt, 2015; Henseler et al., 2009). All the results for the measurement model have been depicted in the following Tables 1, 2 and 3. In addition for Innovation $\mathrm{R}^{2}$ is 0.37 and for FP is 0.45 which shows a substantial effect.

Table 1. Measurement Model of the Study

\begin{tabular}{|c|c|c|c|c|c|}
\hline Constructs & Items & Loadings & Alpha & CR & AVE \\
\hline \multirow[t]{5}{*}{ Board size } & BS1 & 0.837 & 0.851 & 0.9 & 0.693 \\
\hline & BS2 & 0.785 & & & \\
\hline & BS3 & 0.879 & & & \\
\hline & BS4 & 0.825 & & & \\
\hline & BS5 & 0.758 & & & \\
\hline \multirow{3}{*}{ Board independence } & BI1 & 0.543 & 0.758 & 0.839 & 0.512 \\
\hline & BI2 & 0.702 & & & \\
\hline & $\mathrm{BI} 3$ & 0.793 & & & \\
\hline \multirow[t]{6}{*}{ Board diversity } & BOD1 & 0.703 & 0.774 & 0.847 & 0.526 \\
\hline & BOD2 & 0.701 & & & \\
\hline & BOD3 & 0.705 & & & \\
\hline & BOD4 & 0.814 & & & \\
\hline & BOD5 & 0.796 & & & \\
\hline & BOD6 & 0.600 & & & \\
\hline \multirow[t]{4}{*}{ Number of board committee } & NOBC1 & 0.795 & 0.834 & 0.798 & 0.654 \\
\hline & NOBC2 & 0.809 & & & \\
\hline & NOBC3 & 0.839 & & & \\
\hline & NOBC4 & 0.768 & & & \\
\hline \multirow[t]{8}{*}{ Innovation } & INNO1 & 0.806 & 0.876 & 0.80 & 0.645 \\
\hline & INNO 2 & 0.786 & & & \\
\hline & INNO 3 & 0.719 & & & \\
\hline & INNO 4 & 0.657 & & & \\
\hline & INNO 7 & 0.567 & & & \\
\hline & INNO 9 & 0.732 & & & \\
\hline & INNO 10 & 0.802 & & & \\
\hline & INNO 11 & 0.900 & & & \\
\hline \multirow[t]{3}{*}{ Firm performance } & FP1 & 0.591 & 0.898 & 0.917 & 0.704 \\
\hline & FP2 & 0.786 & & & \\
\hline & FP3 & 0.704 & & & \\
\hline
\end{tabular}


JOURNAL OF SECURITY AND SUSTAINABILITY ISSUES

ISSN 2029-7017/ISSN 2029-7025 (online)

2020 Volume 9 January

http://doi.org/10.9770/jssi.2020.9.J(9)

Note: BS-board size, BI-board independence, BOD-board diversity, NOBC-number of board committee, INNOinnovation, FP-firm performance.

Table 2. Fornell and Larcker Criterion for Discriminant Validity

\begin{tabular}{lcccccr}
\hline & BS & BI & BOD & NOBC & INNO & FP \\
\hline BS & $\mathbf{0 . 7 5 5}$ & & & & & \\
BI & 0.436 & $\mathbf{0 . 7 2 2}$ & & & & \\
BOD & 0.522 & 0.437 & $\mathbf{0 . 7 3 6}$ & & & \\
NOBC & 0.434 & 0.51 & 0.563 & $\mathbf{0 . 7 0 9}$ & & \\
INNO & 0.353 & 0.686 & 0.407 & 0.472 & $\mathbf{0 . 7 2 2}$ & $\mathbf{0 . 6 5 5}$ \\
FP & 0.51 & 0.473 & 0.463 & 0.563 & 0.654 & $\mathbf{0 . 6 5 3}$ \\
\hline
\end{tabular}

Note: BS-board size, BI-board independence, BOD-board diversity, NOBC-number of board committee, INNOinnovation, FP-firm performance.

Table 3. HTMT Analysis for Discriminant Validity

\begin{tabular}{|c|c|c|c|c|c|c|}
\hline & $\mathrm{BS}$ & BI & BOD & NOBC & INNO & FP \\
\hline \multicolumn{7}{|l|}{ BS } \\
\hline BI & 0.436 & & & & & \\
\hline BOD & 0.533 & 0.437 & & & & \\
\hline NOBC & 0.434 & 0.51 & 0.563 & & & \\
\hline INNO & 0.353 & 0.686 & 0.407 & 0.472 & & \\
\hline $\mathbf{F P}$ & 0.51 & 0.473 & 0.463 & 0.563 & 0.720 & \\
\hline
\end{tabular}

Note: BS-board size, BI-board independence, BOD-board diversity, NOBC-number of board committee, INNOinnovation, FP-firm performance.

\subsection{Structural Model}

After checking the validation of the model, the structural model of the study was formulated by using the bootstrap 500 resamples which consists of ( $p<0.05$ and t-statistics $>1.96)$. The SEM analysis of the study has been shown that board size (BS) has a positive and significant association with the firm performance (FP). BS also has a positive and significant association with the innovation (INNO). Similarly, it is also found that INNO is partially mediates in the relationship of BS and FP of pharmaceutical industry of the Indonesia. In addition, the board independence (BI) also has a positive and significant association with the FP and BI also has a positive and significant association with the INNO. In the same vein, it is also found that INNO is partially mediates in the relationship of BI and FP of the pharmaceutical industry of the Indonesia. Moreover, it is also found that board diversity (BOD) also has a positive and significant association with the FP and BOD also has a positive and significant association with the INNO. On the other hand, it is found that INNO is not mediates on the relationship of BOD and FP. These findings have shown that INNO is not considered to be significant mediator in the relationship of BOD and FP of the pharmaceutical industry of Indonesia. In addition, it is also found that number of board committee (NOBC) also has insignificant association with the FP but has significant association along with the INNO. Likewise, the INNO has also a partially mediation in the relationship of the NOBC and FP. All of these findings are depicted in the following Table 4. Structural model of the study is provided in figure 2. 
JOURNAL OF SECURITY AND SUSTAINABILITY ISSUES

ISSN 2029-7017/ISSN 2029-7025 (online)

2020 Volume 9 January

http://doi.org/10.9770/jssi.2020.9.J(9)

Table 4. Direct and indirect results of the study

\begin{tabular}{|c|c|c|c|c|c|}
\hline & Beta & S.D & T Statistics & P Values & Results \\
\hline BS ->FP & 0.249 & 0.071 & 3.518 & 0.000 & Supported \\
\hline BS -> INNO & 0.244 & 0.086 & 2.835 & 0.005 & Supported \\
\hline $\begin{array}{c}\text { BS }->\text { INNO ->FP } \\
\text { BI -> FP }\end{array}$ & $\begin{array}{l}0.202 \\
0.178\end{array}$ & $\begin{array}{l}0.075 \\
0.075\end{array}$ & $\begin{array}{l}2.698 \\
2.375\end{array}$ & $\begin{array}{l}0.007 \\
0.018\end{array}$ & $\begin{array}{l}\text { Supported } \\
\text { Supported }\end{array}$ \\
\hline BI -> INNO & 0.281 & 0.055 & 5.113 & 0.000 & Supported \\
\hline BI-> INNO ->FP & 0.259 & 0.067 & 3.878 & 0.000 & Supported \\
\hline BOD -> FP & 0.218 & 0.072 & 3.022 & 0.003 & Supported \\
\hline BOD ->INNO & 0.15 & 0.065 & 2.304 & 0.022 & Supported \\
\hline $\begin{array}{c}\text { BOD-> INNO ->FP } \\
\text { NOBC ->FP } \\
\text { NOBC->INNO }\end{array}$ & $\begin{array}{l}0.043 \\
0.051 \\
0.337\end{array}$ & $\begin{array}{l}0.079 \\
0.091 \\
0.092\end{array}$ & $\begin{array}{l}0.546 \\
0.561 \\
3.653\end{array}$ & $\begin{array}{l}0.586 \\
0.575 \\
0.000\end{array}$ & $\begin{array}{l}\text { Non Supported } \\
\text { Non Supported } \\
\text { Supported }\end{array}$ \\
\hline $\begin{array}{c}\text { NOBC-> INNO ->FP } \\
\text { INNP-> FP }\end{array}$ & $\begin{array}{l}0.043 \\
0.349\end{array}$ & $\begin{array}{l}0.079 \\
0.071\end{array}$ & $\begin{array}{l}0.546 \\
4.915\end{array}$ & $\begin{array}{l}0.586 \\
0.000\end{array}$ & $\begin{array}{l}\text { Supported } \\
\text { Supported }\end{array}$ \\
\hline
\end{tabular}

BS-board size, BI-board independence, BOD-board diversity, NOBC-number of board committee, INNOinnovation, FP-firm performance.

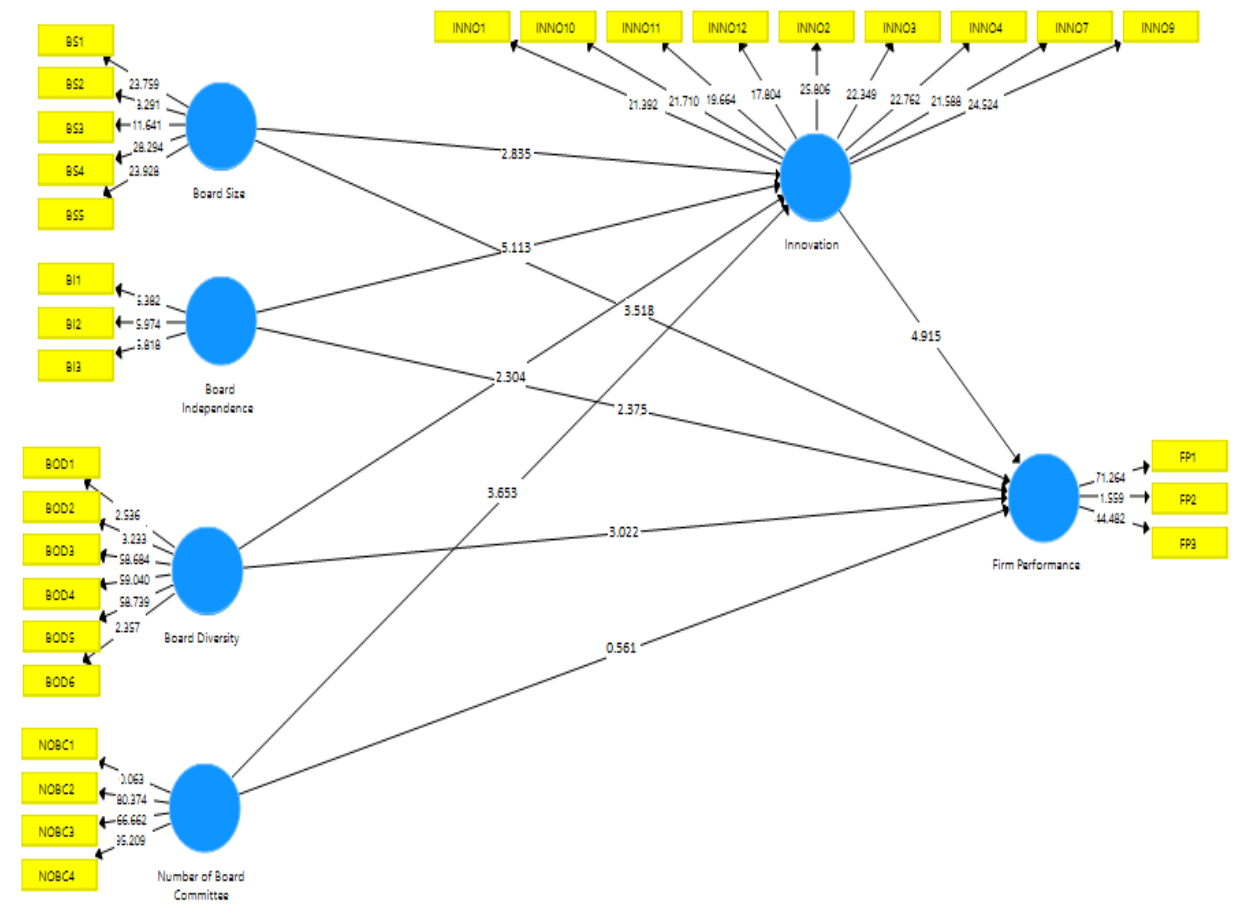

Figure 2. Structural model of the study 
JOURNAL OF SECURITY AND SUSTAINABILITY ISSUES

ISSN 2029-7017/ISSN 2029-7025 (online)

2020 Volume 9 January

http://doi.org/10.9770/jssi.2020.9.J(9)

\section{Conclusions}

The aim of the current study is to investigate the mediating effect of the innovation on the relationship of corporate governance and firm performance of the pharmaceutical industry of Indonesia. To achieve this objective, the following hypothesis of the current study was formulated. The findings of the current study have shown that most of indicators of the corporate governance has a significant relationship with the firm performance. The indirect effect of the findings also shown that innovation is partially mediates on the relationship of corporate governance and firm performance of the pharmaceutical industry of Indonesia. The innovation is not significantly mediate on the relationship of board diversity and firm performance. The findings of the current study are in line with the previous study of (Khan et al., 2019). Based on the findings, study has some implications. The current study could provide help to the corporate governors and policy makers to know about the importance of innovation to increase the performance of the organizations. The current study added a body of literature which could become a new area of research in future. Based on the findings, this study has some limitations, firstly, this study was limited on the single industry, therefore a future research could be established on more industries. Secondly, this study was limited on cross sectional, therefore a future research could be done which is longitudinal. Lastly, the research was limited on individual unit of analysis, therefore a future research could be established that is based on the aggregated manner.

\section{References}

Abeysekera, I. (2010). The influence of board size on intellectual capital disclosure by Kenyan listed firms. Journal of Intellectual Capital, 11(4), 504-518. https://doi.org/10.1108/14691931011085650

Abrams, F. W. (1951). Management's responsibilities in a complex world. Harvard business review, 29(3), 29-34.

Ahmad, R. (2019). Exploring the Relationship of Intellectual Capital, Board Characteristics and Business Performance: A Literature Review. Pakistan Journal of Humanities and Social Sciences, 7(2), 185-202.

Ahmad, R., Bin Mohammad, H., \& Nordin, S. B. (2019). Moderating effect of board characteristics in the relationship of structural capital and business performance: An evidence on Pakistan textile sector. Journal of Studies in Social Sciences and Humanities, 5(3), 89-99.

Ahmad, R., \& Nordin, S. B. (2019). Moderating effect of board characteristics in the relationship of structural capital and business performance: An evidence on Pakistan textile sector. Journal of Studies in Social Sciences and Humanities, 5(3), 89-99.

Ahmed, U., Zin, M. L. M., \& Majid, A. H. A. (2016). Impact of Intention and Technology Awareness on Transport Industry's E-service: Evidence from an Emerging Economy. 산경연구논집 (IJIDB), 7(3), 13-18.

Al-Okaily, J., \& Naueihed, S. (2019). Audit committee effectiveness and family firms: impact on performance. Management decision. https://doi.org/10.1108/MD-04-2018-0422

Ali, M. (2018). Impact of Corporate Governance on Firm's Financial Performance (A Comparative Study Of Developed And Non Developed Markets). Economic Research, 2(1), 15-30. https://doi.org/10.29226/TR1001.2018.7 
JOURNAL OF SECURITY AND SUSTAINABILITY ISSUES

ISSN 2029-7017/ISSN 2029-7025 (online)

2020 Volume 9 January

http://doi.org/10.9770/jssi.2020.9.J(9)

Anand, R., \& Singh, B. (2019). Do Firm-and Board-specific Characteristics Corroborate Underpricing? A Study on the Indian IPOs. Management and Labour Studies, 44(1), 86-102. https://doi.org/10.1177/0258042X18812582

Arniati, T., Puspita, D.A., Amin, A., Pirzada, K. (2019). The implementation of good corporate governance model and auditor independence in earnings' quality improvement. Entrepreneurship and Sustainability Issues, 7(1), 188-200. http://doi.org/10.9770/jesi.2019.7.1(15)

Balsmeier, B., Fleming, L., \& Manso, G. (2017). Independent boards and innovation. Journal of financial economics, $123(3)$, 536-557. https://doi.org/10.1016/i.jfineco.2016.12.005

Barnhart, S. W., Marr, M. W., \& Rosenstein, S. (1994). Firm performance and board composition: Some new evidence. Managerial and decision economics, 15(4), 329-340. https://doi.org/10.1002/mde.4090150407

Berkman, H., Zou, L., \& Geng, S. (2009). Corporate governance, profit manipulation and stock return. Journal of International Business and Economics, 9(2), 132-145.

Bhagat, S., \& Bolton, B. (2008). Corporate governance and firm performance. Journal of corporate finance, 14(3), 257-273. https://doi.org/10.1016/j.jcorpfin.2008.03.006

Bhagat, S., \& Bolton, B. (2019). Corporate governance and firm performance: The sequel. Journal of corporate finance, 58, $142-168$. https://doi.org/10.1016/i.jcorpfin.2008.03.006

Carter, D. A., D'Souza, F., Simkins, B. J., \& Simpson, W. G. (2010). The gender and ethnic diversity of US boards and board committees and firm financial performance. Corporate Governance: An International Review, 18(5), 396-414. https://doi.org/10.1111/j.1467$\underline{8683.2010 .00809 . x}$

Dalton, D. R., Daily, C. M., Ellstrand, A. E., \& Johnson, J. L. (1998). Meta-analytic reviews of board composition, leadership structure, and financial performance. Strategic management journal, 19(3), 269-290. https://doi.org/10.1002/(SICI)1097-0266(199803)19:3\%3C269::AID$\underline{\text { SMJ950\%3E3.0.CO;2-K }}$

Darroch, J. (2005). Knowledge management, innovation and firm performance. Journal of Knowledge Management, 9(3), 101-115. https://doi.org/10.1108/13673270510602809

Darroch, J., \& Jardine, A. (2002). Combining firm-based and consumer-based perspectives to develop a new measure for innovation.

Ebun, A. F. (2019). The Impact of Audit Committee on Financial Performance of Insurance Firms in Nigeria. https://doi.org/10.7176/RJFA/10-14-02

Fagan, C., Menèndez, M. G., \& Ansón, S. G. (2012). Women on corporate boards and in top management: European trends and policy: Springer.

Fogarassy, C., Neubauer, É., Mansur, H., Tangl, A., Oláh, J., \& Popp, J. (2018). The main transition management issues and the effects of environmental accounting on financial performance-with focus on cement industry. Administratie si Management Public (31), 52-66. https://doi.org/10.24818/amp/2018.31-04

Gkliatis, I., Tsene, C., \& Koufopoulos, D. (2019). Corporate governance and board configuration in Greece. Board of directors and company performance: An international outlook.

Hair, Hollingsworth, C. L., Randolph, A. B., \& Chong, A. Y. L. (2017). An updated and expanded assessment of PLS-SEM in information systems research. Industrial Management \& Data Systems, 117(3), 442-458. https://doi.org/10.1108/IMDS-04-2016-0130 
JOURNAL OF SECURITY AND SUSTAINABILITY ISSUES

ISSN 2029-7017/ISSN 2029-7025 (online)

2020 Volume 9 January

http://doi.org/10.9770/jssi.2020.9.J(9)

Hasanudin, A.I., Yuliansyah, Y., Said, J., Susilowati, Ch., Muafi. (2019). Management control system, corporate social responsibility, and firm performance. Entrepreneurship and Sustainability Issues, 6(3), 1154-1168. http://doi.org/10.9770/jesi.2019.6.3(21)

Henri, J.-F. (2006). Management control systems and strategy: A resource-based perspective. Accounting, Organizations and Society, 31(6), 529-558. https://doi.org/10.1016/j.aos.2005.07.001

Henseler, J., Ringle, C. M., \& Sarstedt, M. (2015). A new criterion for assessing discriminant validity in variance-based structural equation modeling. Journal of the academy of marketing science, 43(1), 115-135. https://doi.org/10.1007/s11747-014-0403-8

Henseler, J., Ringle, C. M., \& Sinkovics, R. R. (2009). The use of partial least squares path modeling in international marketing. In New challenges to international marketing (pp. 277-319): Emerald Group Publishing Limited. https://doi.org/10.1108/S1474$\underline{7979(2009) 0000020014}$

Hillman, A. J., Withers, M. C., \& Collins, B. J. (2009). Resource dependence theory: A review. Journal of management, 35(6), $1404-1427$. https://doi.org/10.1177\%2F0149206309343469

Honghui, L., Gacheru, F., Waichigo, J., Nzuki, B. M., Meja, E. W., Olonde, J. O., . . Patrick, M. S. (2017). The effect of Corporate Governance on Performance of firms listed on the nairobi securities exchange. In: School of business, University of Nairobi.[Google Scholar].

Hussain, H.I., Ali, A., Thaker, H.M.T., \& Ali., M. (2019) Firm Performance and Family Related Directors: Empirical Evidence from an Emerging Market, Contemporary Economics, 13 (2), 187-204.

Jensen, J. S. (2019). What is religion? : Routledge.

Jermsittiparsert, K. \& Boonratanakittiphumi, C. (2019). The Mediating Role of Knowledge Management and the Moderating Role of Additive Manufacturing (Industry 4.0) in the Relationship between Knowledge Management Capability and Firm Performance: A Case of KPMG Thailand. International Journal of Innovation, Creativity and Change, 8(8), 430-449.

Kaplan, R. S., \& David, P. (1996). Norton. 1996. The balanced scorecard: translating strategy into action.

Kaplan, R. S., \& Norton, D. P. (2007). Using the balanced scorecard as a strategic management system. Harvard business review, 85(7-8), $150-+$.

Kariyawasam, A. (2014). Impact of management control systems on the return on sales of manufacturing companies in Sri Lanka. Journal of Business and Retail Management Research, 8(2).

Khan, S. N., Hussain, R. I., -Ur-Rehman, S., Maqbool, Q., Engku ALI, E. I., \& Numan, M. (2019). The mediating role of Innovation between Corporate Governance and Organizational Performance: Moderating role of Innovative Culture in Pakistan Textile Sector. Cogent Business \& Management (just-accepted), 1631018. https://doi.org/10.1080/23311975.2019.1631018

Kiel, G., \& Blennerhasett, P. (1984). The board of directors in large Australian companies. Management decision, 22(1), 40-44.

Klein, P., Shapiro, D., \& Young, J. (2005). Corporate governance, family ownership and firm value: the Canadian evidence. Corporate Governance: An International Review, 13(6), 769-784. https://doi.org/10.1111/j.1467-8683.2005.00469.x

Kooijman, F. F. (2017). Monitoring effectiveness of supervisory boards in the Dutch semi-public sector.

Kotlar, J., Cuomo, F., Gaia, S., \& Zattoni, A. (2019). Corporate Governance in large UK family firms. In: IFB Research Foundation.

Lam, T.-y., \& Lee, S.-k. (2012). Family ownership, board committees and firm performance: evidence from Hong Kong. Corporate Governance: The International Journal of Business in Society, 12(3), 353-366. https://doi.org/10.1108/14720701211234609 
JOURNAL OF SECURITY AND SUSTAINABILITY ISSUES

ISSN 2029-7017/ISSN 2029-7025 (online)

2020 Volume 9 January

http://doi.org/10.9770/jssi.2020.9.J(9)

Larcker, D., Richardson, S. A., Seary, A. J., \& Tuna, I. (2006). Director networks, executive compensation, and organizational performance.

Letza, S., Sun, X., \& Kirkbride, J. (2004). Shareholding versus stakeholding: A critical review of corporate governance. Corporate Governance: An International Review, 12(3), 242-262. https://doi.org/10.1111/j.1467-8683.2004.00367.x

Lin, J. B., Pantzalis, C., \& Park, J. C. (2010). Corporate hedging policy and equity mispricing. Financial Review, 45(3), 803-824. https://doi.org/10.1111/j.1540-6288.2010.00272.x

Malkawi, B. H. (2019). Conference on Corporate Governance: Search for the Advanced Practices.

Mansur, H., \& Tangl, A. (2018). The Effect of Corporate Governance on the Financial Performance of Listed Companies in Amman Stock Exchange (Jordan). Journal of Advanced Management Science Vol, 6(2), 97-102. https://doi.org/10.18178/joams.6.2.97-102

Mbalwa, P. n., Kombo, H., Chepkoech, L., \& Shavulimo, P. M. (2014). Effect of Corporate Governance on Performance of Sugar Manufacturing Firms in Kenya: A Case of Sugar Manufacturing Firms in Western Keny. Journal of Business and Management, 16(11), 214239.

Menguc, B., \& Auh, S. (2006). Creating a firm-level dynamic capability through capitalizing on market orientation and innovativeness. Journal of the academy of marketing science, 34(1), 63-73. https://doi.org/10.1177/0092070305281090

Miller, T., \& del Carmen Triana, M. (2009). Demographic diversity in the boardroom: Mediators of the board diversity-firm performance relationship. Journal of management studies, 46(5), 755-786. https://doi.org/10.1111/j.1467-6486.2009.00839.x

Mohammed, B. H., Flayyih, H. H., Mohammed, Y. N., \& Abbood, H. Q. (2019). The effect of audit committee characteristics and firm financial performance: An empirical study of listed companies in Iraq stock exchange. Journal of Engineering and Applied Science, 14(4), 4919-4926. http://dx.doi.org/10.36478/jeasci.2019.4919.4926

Moses, T. (2019). Board Characteristics, Audit Committee Composition and Financial Reporting in Nigeria. International Journal of Innovative Social Sciences \& Humanities Research, 7(1), 37-45

Patidar, R., \& Din, T. M. U. (2018). A Study on the Fluctuating Trend of Export (Demand Change) of 'Garlic of India' by its Price Transformation in International Markets, Under the Time Period of 1991 to 2011. International Journal of Applied Economics, Finance and Accounting, 2(2), 54-59. https://doi.org/10.33094/8.2017.2018.22.54.59

Pfeffer, J. (1972). Size and composition of corporate boards of directors: The organization and its environment. Administrative science quarterly, 17(2), 218-228. https://doi.org/10.2307/2393956

Plazzi, A., Torous, W. N., \& Yilmaz, U. (2019). Does Corporate Governance Matter? Evidence from the AGR Governance Rating. Evidence from the AGR Governance Rating (October 10, 2019). Swiss Finance Institute Research Paper (16-54). https://dx.doi.org/10.2139/ssrn.2836370

Puni, A. (2015). Do board committees affect corporate financial performance? Evidence from listed companies in Ghana. International Journal of Business and Management Review, 3(5), 14-25.

Rankin, M., Stanton, P., McGowan, S., Ferlauto, K., \& Tilling, M. (2012). Contemporary issues in accounting.

Rehman, S. U., Mohamed, R., \& Ayoup, H. (2018). Management Control System (MCS) as a package elements influence on organizational performance in the Pakistani context. Pakistan Journal of Humanities and Social Sciences, 6(3), 280-295. 
JOURNAL OF SECURITY AND SUSTAINABILITY ISSUES

ISSN 2029-7017/ISSN 2029-7025 (online)

2020 Volume 9 January

http://doi.org/10.9770/jssi.2020.9.J(9)

Spira, L. F., \& Bender, R. (2004). Compare and contrast: perspectives on board committees. Corporate Governance: An International Review, 12(4), 489-499. https://doi.org/10.1111/j.1467-8683.2004.00389.x

Sriviboon, C. \& Jermsittiparsert, K. (2019). Influence of Human Resource Practices on Thai Pharmaceutical Firm Performance with Moderating Role of Job Involvement. Systematic Reviews in Pharmacy, 10(2), 234-243. https://doi.org/10.5530/srp.2019.2.31

Taljaard, C. C., Ward, M. J., \& Muller, C. J. (2015). Board diversity and financial performance: A graphical time-series approach. South African Journal of Economic and Management Sciences, 18(3), 425-447. https://doi.org/10.17159/2222-3436/2015/V18N3A10

Thrikawala, S., Locke, S., \& Reddy, K. (2016). Board structure-performance relationship in microfinance institutions (MFIs) in an emerging economy. Corporate Governance: The International Journal of Business in Society, 16(5), 815-830. https://doi.org/10.1108/CG-12-2015$\underline{0166}$

Turulja, L., \& Bajgoric, N. (2018). Information technology, knowledge management and human resource management: investigating mutual interactions towards better organizational performance. VINE Journal of Information and Knowledge Management Systems, 48(2), 255-276. https://doi.org/10.1108/VJIKMS-06-2017-0035

Verhees, F. J., \& Meulenberg, M. T. (2004). Market orientation, innovativeness, product innovation, and performance in small firms. Journal of Small Business Management, 42(2), 134-154. https://doi.org/10.1111/j.1540-627X.2004.00102.x

Villalonga, B., \& Amit, R. (2006). How do family ownership, control and management affect firm value? Journal of financial economics, 80(2), 385-417. https://doi.org/10.1016/j.jfineco.2004.12.005

Wallach, E. J. (1983). Individuals and organizations: The cultural match. Training \& Development Journal, 37(2), 28-36.

Zaefarian, G., Forkmann, S., Mitręga, M., \& Henneberg, S. C. (2017). A capability perspective on relationship ending and its impact on product innovation success and firm performance. Long Range Planning, 50(2), 184-199. https://doi.org/10.1016/j.lrp.2015.12.023

Zulfiqar, M., \& Hussain, K. (2019). CEO compensation and firm innovation: moderating role of ownership concentration. International Journal of Innovation Management, 2050058. https://doi.org/10.1142/S1363919620500589

Witthaya MEKHUM is an Associate Professor and the Vice President for Planning and Quality Assurance of Suan Sunandha Rajabhat University, Thailand. His research areas are Industrial Technology, Security Management, and Material Management. ORCID ID: orcid.org/0000-0002-9667-3730

This work is licensed under the Creative Commons Attribution International License (CC BY). http://creativecommons.org/licenses/by/4.0/

CC) (i) Open Access 